Research Article

\title{
Chloride Diffusivity in Blended Cement Made from Selected Industrial and Agrowastes
}

\author{
Jackson Muthengia Wachira $\mathbb{( D D}^{1}$ and Joseph Mwiti Marangu ${ }^{2}$ \\ ${ }^{1}$ Department of Physical Sciences, University of Embu, Embu, Kenya \\ ${ }^{2}$ Department of Physical Sciences, Meru University of Science \& Technology, Meru, Kenya \\ Correspondence should be addressed to Joseph Mwiti Marangu; jmarangu2011@gmail.com
}

Received 5 March 2019; Revised 19 May 2019; Accepted 4 June 2019; Published 16 June 2019

Academic Editor: Jose M. Monzo

Copyright ( 2019 Jackson Muthengia Wachira and Joseph Mwiti Marangu. This is an open access article distributed under the Creative Commons Attribution License, which permits unrestricted use, distribution, and reproduction in any medium, provided the original work is properly cited.

\begin{abstract}
This paper reports study findings on the diffusivity of chloride ions in potential blended cement. The cement, abbreviated as PCDC, was made from blending ordinary Portland cement (OPC) with dried calcium carbide residue and an incinerated mix of rice husks, spent bleaching earth, and broken bricks. The aim of the study was to investigate the ability of PCDC to withstand aggressive chloride environment. $10 \mathrm{~cm} \times 10 \mathrm{~cm}$ mortar cubes were prepared using PCDC and cured for 28 days in saturated calcium hydroxide solution. The cured mortar cubes were subjected to aggressive chloride media in a laboratory set up. The test cement was subjected to chloride profile analysis with depth of cover as a function of w/c ratio and curing period in alternate dry and wet environments of 3.5 percent sodium chloride solution. The experiments were carried alongside neat OPC and OPC $+25 \%$ pulverised fuel ash (OPC + 25\% PFA). Results showed that PCDC exhibited lower chloride ingress as the depth of cover increased. In conclusion, the study showed that PCDC was a potential cementitious material with high ability to withstand aggressive environment of chlorides.
\end{abstract}

\section{Introduction}

The need to promote safe and economical waste management practices has led to the utilisation of waste materials in the manufacture of blended cements globally. Such wastes include rice husk (RH), spent bleaching earth (SBE), ground granulated blast-furnace slag (GGBS), waste tyres, broken or reject bricks (BB), silica fumes, pulverised fuel ash (PFA), and dried calcium carbide residue (DCCR), among others [1]. Exposure of cementitious materials to aggressive environmental conditions affects their durability properties and their ultimate service life [2-8]. The ability to withstand aggressive environment has remained a major challenge to a majority of the cement-based materials.

Salty environments have been observed to be deleterious in cementitious products [9]. This is mainly manifested in terms of corrosion of the rebar if chlorides are present in the concrete or mortar $[8,10-14]$. Other known effects are characterised expansion, cracking, and sprawling of the concrete mass, among other effects [15]. In Mg attack, conversion of the cementitious products to a mushy noncementitious material has been observed [16]. This has been observed, for example, where the magnesium sulphate is converted to magnesium hydroxide $(\mathrm{MH})$ upon reaction with calcium hydroxide. The resultant $\mathrm{MH}$ can attack the silicate hydrates forming the mushy noncementitious magnesium silicate hydrates (MSH) [17].

The major sources of chlorides to concrete can be either from the mixing water or externally, for example, brackish water, sea water, and industrial effluents, among others [2]. The ingress of chlorides into the concrete occurs in a manner similar to other pollutants [2]. This is mainly through diffusion in the pore water, adsorption (and desorption) onto the pore walls, and hydrodynamic dispersion and convection due to the flow of the pore water $[5,18,19]$. Adsorption occurs in concrete layers exposed to wet and dry cycles and is mainly limited to $10-20 \mathrm{~mm}$ of the concrete surface [20]. Ingress of chlorides into the concrete can also take place 
through capillary action via cracks and continuous pores except in saturated concrete material.

The rate of ingress of chloride is dependent on the cement type, age, w/c ratio, blended or neat OPC, porosity, binding ability of the chlorides, and the accompanying cation of the chlorides [21-27]. $\mathrm{Ca}^{2+}$ and $\mathrm{Mg}^{2+}$ show higher chloride diffusivity than $\mathrm{Na}^{+}$[28-31]. Blended cements, for example, pozzolana based, are less permeable due to increased cementitious material from the reaction between the included pozzolana and $\mathrm{Ca}(\mathrm{OH})_{2}$ resulting from hydration of cement [32-34]. Blended cements have also exhibited higher binding ability of chlorides, because of the proportionate amount of alumina if it forms part of the reactive phase, and hence decrease chloride diffusion [2]. Chlorides, although the accompanying cation may, generally have no effect on the calcium silicate hydrates of cement [35]. They have only been shown to interact with the alumina content of cement. It is widely documented that chloride is extremely harmful to the reinforcement bar beyond certain critical threshold concentration where it induces pitting and propagates corrosion of the rebar [36].

Pozzolanicity and compressive strength development of PCDC either in blend with commercial building lime, dried calcium carbide residue, or with OPC has previously been reported [1]. The present study aimed to investigate the performance of PCDC in a laboratory set up simulating the ordinary environmental corrosive media encountered in day to day's life in the construction industry. This involved subjecting the cement mortar in a 3.5 percent sodium chloride media and analysing the chloride content at different depths from the exposed surface in a one-dimensional mode of diffusion in to the cement mortar. The mortar cubes were subjected to the dry and wet environments for a period of about six months.

\section{Materials and Methods}

2.1. Materials. Materials were sampled from Kenyan local industrial, processing, or manufacturing plants. A mixed incineration of $\mathrm{RH}, \mathrm{SBE}$, and ground $\mathrm{BB}$ was prepared by spreading $5 \mathrm{~kg}$ of rice husks at the basement of a fixed bed kiln followed by a thin layer of $8 \mathrm{~kg}$ of ground $\mathrm{BB}$ as detailed in [1]. $5 \mathrm{~kg}$ of $\mathrm{RH}$ were spread on the BB followed by $8 \mathrm{~kg}$ of SBE then finally $30 \mathrm{~kg}$ of $\mathrm{RH}$ covered the whole mass. Through the firing window, a little amount of paraffin was spread over the $\mathrm{RH}$ and the material ignited. Temperatures were controlled below $700^{\circ} \mathrm{C}$ through opening and closing of the kiln windows. After about 48 hours, the un-burnt upper surface layer was skimmed off. The resultant ash was thoroughly mixed then ground using a laboratory ball mill mode TR $850 \mathrm{~W}$ until the percent retention on a $100 \mu \mathrm{m}$ shaker sieve was less than 10 percent. The resultant ash was labelled CSBR.

CSBR was mixed with OPC to make a 45 percent substituted OPC. This was labelled PCDC in this work. PFA and OPC were used as obtained from the Mechanical and Civil Engineering School of the University of Manchester. The chemical analysis of the test material used is given in Table 1 as obtained from the X-ray fluorescence analysis.
TABLE 1: Results of chemical analysis of the test materials used.

\begin{tabular}{lccc}
\hline Oxide (\%) & OPC & $\begin{array}{c}\text { Sample } \\
\text { PFA }\end{array}$ & Test ash \\
\hline $\mathrm{SiO}_{2}$ & 16.163 & 39.417 & 39.711 \\
$\mathrm{CaO}$ & 64.615 & 3.691 & 23.742 \\
$\mathrm{Al}_{2} \mathrm{O}_{3}$ & 3.831 & 16.951 & 4.849 \\
$\mathrm{Fe}_{2} \mathrm{O}_{3}$ & 2.527 & 3.000 & 4.043 \\
$\mathrm{Na}_{2} \mathrm{O}$ & 0.252 & 0.242 & 0.173 \\
$\mathrm{~K}_{2} \mathrm{O}$ & 0.572 & 1.482 & 0.824 \\
$\mathrm{MgO}$ & 0.832 & 1.06 & 0.524 \\
$\mathrm{SO}_{3}$ & 3.573 & 0.734 & 0.485 \\
$\mathrm{Cl}^{-}$ & 0.027 & 0.02 & 0.061 \\
\hline
\end{tabular}

\subsection{Methods}

2.2.1. Mortar Preparation and Curing. 3:1 sand to binder $(100 \%$ OPC, OPC + 25\% PFA, or PCDC) ratio was used in the preparation of the mortar. In the initial stages, it was presumed that mortar with $0.4,0.5$, and $0.6 \mathrm{w} / \mathrm{c}$ ratios would be prepared. It was however noted that the amount of water added to correspond with the above w/c ratios could not make consistent pastes. This was because the sand was ovendried. The amount of water required to wet the sand was determined through the addition of excess water to the sand and leaving the sand to dry in a normal laboratory set up for three days. The residual water was calculated to be about 0.077 percent by weight. A $0.8 \mathrm{w} / \mathrm{c}$ ratio mortar proved to be the best workable mix in all cement categories. A lower w/c ratio of 0.73 was also used, but the paste was quite difficult to work with. A higher w/c ratio of 0.85 was also prepared. A corrected $\mathrm{w} / \mathrm{c}$ ratio after subtracting the sand wetting water would correspond to $0.5,0.57$, and 0.62 for $0.73,0.8$, and 0.85 , respectively. To avoid confusion, the later $\mathrm{w} / \mathrm{c}$ ratios have been used in this paper.

Mortar was prepared in the usual manner using "CreteAngle Multiflow Mixer," commonly referred as Pan Mixer, by first mixing the dry powder (cement and sand in $1: 3$ ratio) and then adding and mixing corresponding amounts of water. The mortar was finally compacted into $100 \mathrm{~mm}$ cube moulds using a vibrating table. Three mortar cubes were prepared for each category of cement and w/c ratio. The resultant mortar was cured for 24 hours (in case of 0.73 and $0.8 \mathrm{w} / \mathrm{c}$ ratios) and 48 hours (in case of $0.85 \mathrm{w} / \mathrm{c}$ ratio) after which they were demoulded. After demoulding all the cubes, steel reinforcement protector 841, obtained from Flexcrete Technologies Limited (UK), was applied to all faces, except on two opposite sides, of the mortar cubes. The steel reinforcement protector 841 was prepared and applied as per the manufacturer's instructions. After the $28^{\text {th }}$ day of curing in saturated calcium hydroxide solution, all cubes were subjected to one week alternate wet-dry tank for a period of six months. The wet alternate week involved complete immersion of the mortar cubes in 3.5 percent sodium chloride solution.

2.2.2. Chloride Ingress Profile Analysis. On the two opposite sides to which steel reinforcement protector 841 paste was not applied, an emery paper 80 grit was used to polish to 
about $1 \mathrm{~mm}$ layer. A 15 by $15 \mathrm{~mm}$ by $100 \mathrm{~mm}$ core was obtained from each cured mortar cubes. This was done by cutting the mortar cubes using a Slabbing saw with a 14 -inch blade using water as lubricant. The obtained core was cut first into two equal portions of $15 \mathrm{~mm}$ by $15 \mathrm{~mm}$ by $50 \mathrm{~mm}$. The two halves were cut into four equal slices to give samples at depths of $12.5,25,37.5$, and $50 \mathrm{~mm}$ using CS 10 Logitech saw with a 10 -inch blade. The obtained slices were ground using a Tema equipment grinder for two minutes. Between each sample grinding, the grinder was thoroughly cleaned to avoid cross contamination. The ground samples were placed in a $20 \mathrm{ml}$ glass sample holder and shaken to mix.

The chloride profile analysis was done in accordance with ASTM C 1152 (ASTM 2005) [37] with slight modifications: a corning chloride analyzer M926 apparatus was used instead of the prescribed silver-silver chloride electrode for the determination of chloride concentrations. The resultant nitric acid extracts from the cement mortar were therefore adjusted to $\mathrm{pH}$ of about 7 with sodium hydroxide solution. The rest of the procedure was adopted.

About $10 \mathrm{~g}$ of the sample from the mortar cube drills was obtained for analysis. The sample was dispersed in $75 \mathrm{~mL}$ of water in a $250 \mathrm{~mL}$ beaker. $25 \mathrm{~mL}$ of [1:1] nitric acid was slowly added while stirring with a glass rod to break any lump of cement forming. The beaker's content, with a watch glass cover lid on, was rapidly brought to boiling using a hot plate. The resultant solution was allowed to cool for about ten minutes, and then its $\mathrm{pH}$ was adjusted to neutral. The neutral solution was then filtered through a prerinsed $9 \mathrm{~cm}$ course textured filter paper into a $250 \mathrm{~mL}$ beaker. The filter paper and the beaker were rinsed four times with water. The filtrate was diluted to $200 \mathrm{ml}$ in a volumetric flask. The resultant solution was then analysed for chlorides using the Corning Chloride Analyzer M926 of serial number 1845. The chloride analyzer M926 was first conditioned with $5 \mu \mathrm{l}$ of a 200 ppm standard chloride solution in mix with $30 \mathrm{ml}$ of ionic strength adjustment buffer solution, provided for the analyzer. A standard calibration curve was obtained from 0 to $200 \mathrm{ppm}$ standard chloride solutions. $5 \mu \mathrm{l}$ of $200 \mathrm{ppm}$ chloride solution (provided with the apparatus) was pipetted into a $30 \mathrm{ml}$ buffer solution. The machine was then conditioned by pressing the "run-condition" button. Additional $5 \mu \mathrm{l}$ of $200 \mathrm{ppm}$ chloride solution was pipetted into the buffer solution and the machine set to analyse. The procedure was repeated until a reading of $200 \pm 2$ units was obtained. For sample analysis, $5 \mu \mathrm{l}$ of $200 \mathrm{ppm}$ standard chloride solution (provided with the apparatus) were pipetted into a $30 \mathrm{ml}$ buffer solution and the machine conditioned as above. $5 \mu \mathrm{l}$ of sample was then pipetted into the resultant solution and the machine set to analyse. The conditioning and calibration was always run each time a new series of sample was analysed. For each analysis, quadruplicate results were run for every three samples of a given cement type. Since there was a slight deviation from the prescribed standard (ASTM, 2005e) procedure, confirmatory tests were run. This was first through carrying out the above sample digestion process of a mortar sample and obtaining the residue after filtration. The residue was washed further for three more times and reacidified to a $\mathrm{pH}$ of 2 using the $1: 1 \mathrm{HNO}_{3}$. To the reacidified sample, a few drops of silver nitrate solution were added. No white precipitates were observed as would have been expected of a chloride-containing solution. A second confirmatory test involved a mortar sample that was divided into two portions. To one portion, $40 \mathrm{ml}$ of $200 \mathrm{ppm}$ chloride solution was added as part of the $75 \mathrm{ml}$ dispersing water, and the normal sample digestion and chloride analysis was performed. This was performed in triplicates. The results showed a corresponding response to the added chloride standard as compared to the unspiked samples. Results obtained were used to plot chloride profiles where the chloride content was expressed as percent by mass of mortar.

\section{Results and Discussion}

3.1. Chloride Ingress. Figures $1-3$ show the chloride profiles against the depth from exposed surface of each category of the mortar cubes. Codes were used to represent the cement type and w/c. PC represented PCDC, OP for OPC, and PF for OPC $+25 \%$ PFA. Code 12 represented w/c of 0.73 , code 30 for $\mathrm{w} / \mathrm{c}$ of 0.8 , and code 29 for $\mathrm{w} / \mathrm{c}$ of 0.85 . Thus the full code "PC12" represented the mortar PCDC with a w/c of 0.73 .

It was observed that as the w/c ratio increased, there was a marked rise in the total chloride ingress in all the profile depths of the test cements. Blended cements, OPC $+25 \%$ PFA and PCDC, showed lower total chloride ingress than OPC. The order was $\mathrm{OPC}+25 \%$ PFA $<\mathrm{PCDC}<\mathrm{OPC}$. PCDC showed a significant decrease in chloride ingress as the depth of cover increased. This was even more pronounced as the w/c ratio reduced. As observed for the $\mathrm{OPC}+25 \%$ PFA and PCDC, there was a high chloride concentration at the shallow depth from exposed surface, which decreased with depth compared to the OPC. This could be attributed to changes in the intrinsic diffusivity and chloride binding capacity of the cement involved [24]. Pozzolana is known to decrease the diffusion coefficients of chlorides for a given accompanying cation. This reduces its diffusion rates into the cement bulk [38]. This is mainly attributed to the increased chloride binding ability by the mortar at the surface due to increased content of CSH and aluminate phases $[2,24]$.

As the depth of profile increased, it was observed that the OPC exhibited the highest chloride ingress especially at higher w/c ratios. These observations are consistent with those reported in similar studies elsewhere [2, 39, 40]. They attributed the reduction in ingress in pozzolana-based material to reduced porosity, denser mortar, pore refinement, decreased chloride diffusivity, and higher binding ability.

It was observed that as the $\mathrm{w} / \mathrm{c}$ increased, there was an increase in the chloride ingress across all the test cements. The difference was dependent on the depth of the cover which was again dependent on the category of cement. As the $\mathrm{w} / \mathrm{c}$ ratio increases, the porosity of the resultant mortar increases [41]. This results in a higher diffusivity of the chloride into the mortar. Figures 1 and 2, for example, show that for blended cements, the difference due to w/c was only significant at the shallow depth from exposed surface. For 


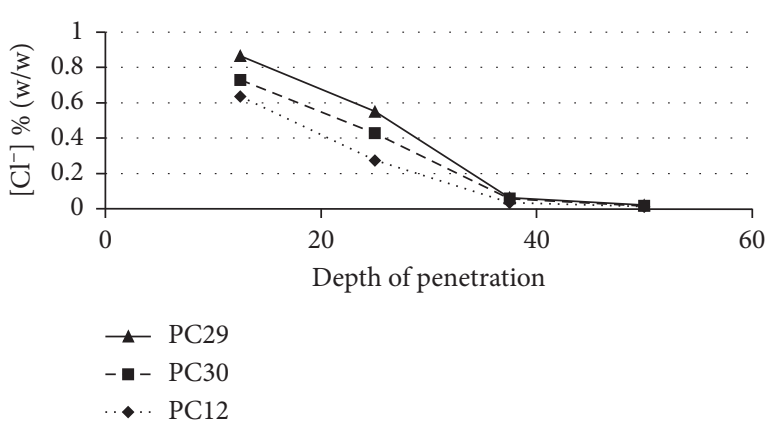

Figure 1: Results for chloride ingress versus depth from exposed surface for PCDC.

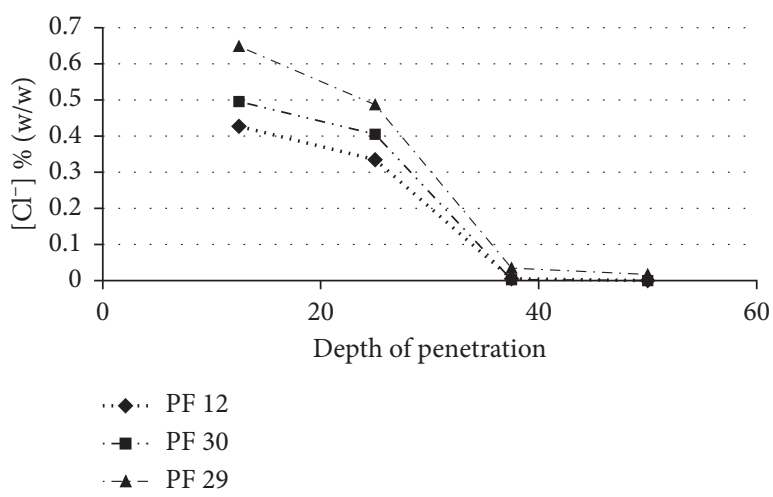

Figure 2: Results for chloride ingress versus depth from exposed surface for OPC $-25 \%$ PFA.

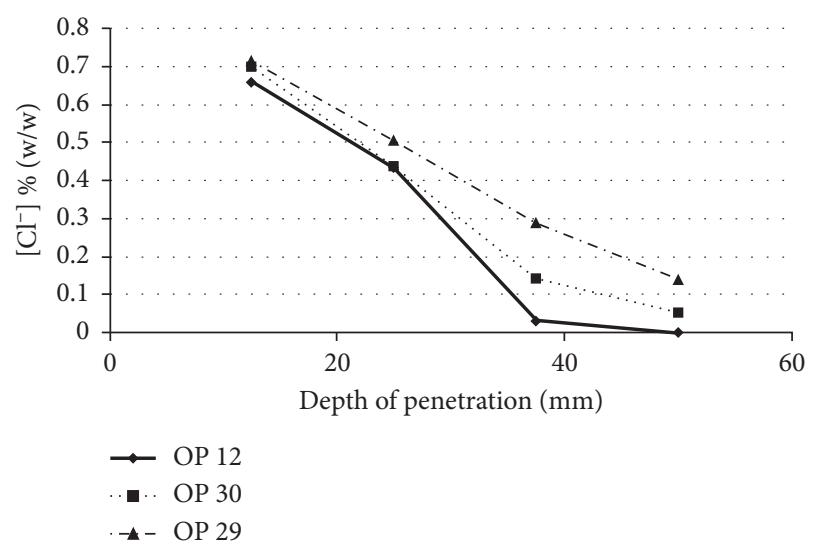

Figure 3: Results for chloride ingress versus depth from exposed surface OPC.

OPC, the difference due to w/c was within the bulk (c/f Figure 3 with Figures 1 and 2). These observations were similar to the ones in [42].

From the study, it was found necessary to plot comparative graphs between the different cement types for each w/c ratio. This helped in obtaining a clear picture of the differences, if any, on the ingress of the chlorides into the cement mortars. Figures 4-6 show the chloride profiles of the different categories of cements at specified w/c ratios.

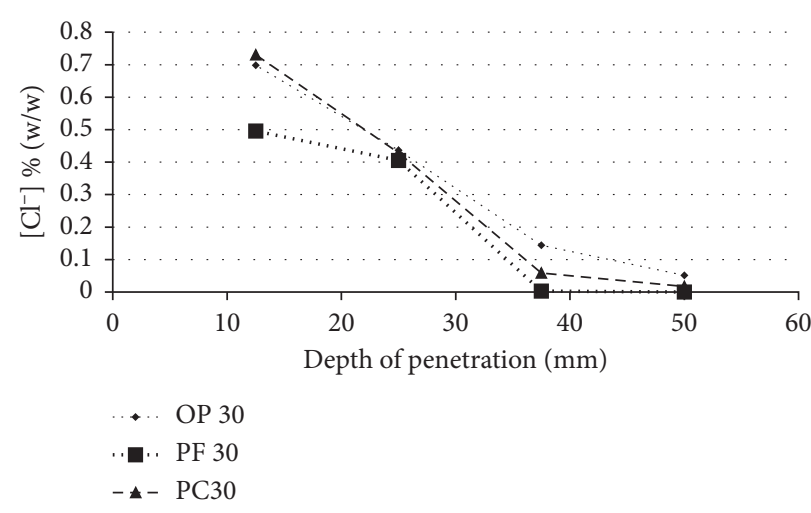

FIgURE 4: Results for chloride ingress versus depth from exposed surface test cements at $0.8 \mathrm{w} / \mathrm{c}$ ratio.

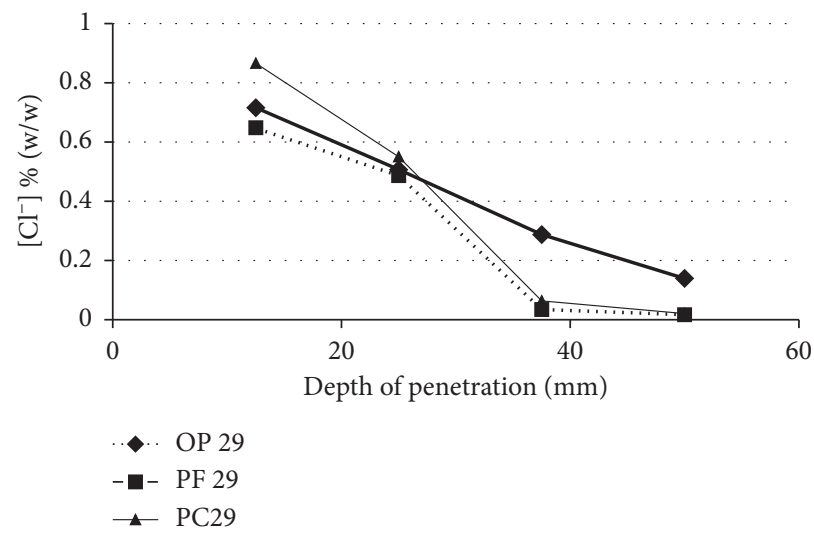

Figure 5: Results for chloride ingress versus depth from exposed surface for the test cements at $0.85 \mathrm{w} / \mathrm{c}$ ratio.

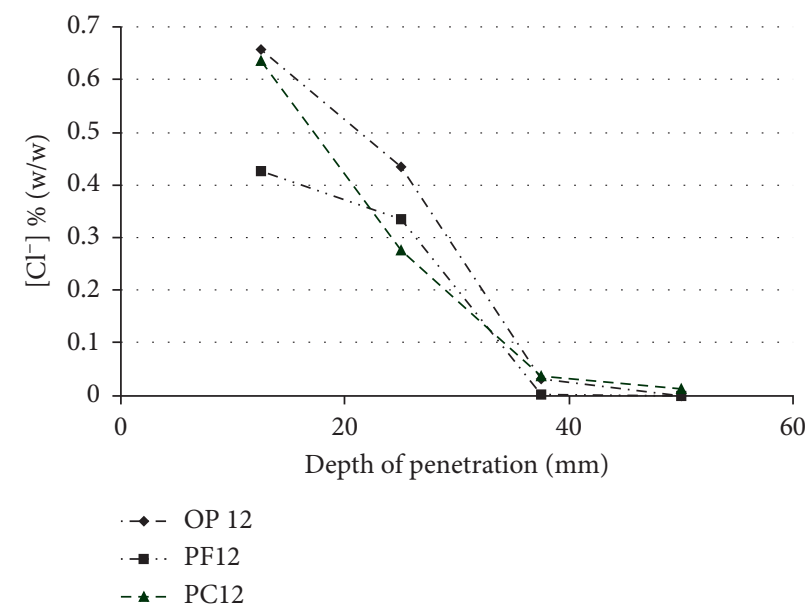

FIgURE 6: Results for chloride ingress versus depth from exposed surface for the test cements at $0.73 \mathrm{w} / \mathrm{c}$ ratio.

There was an observed slight lower chloride ingress in OPC $+25 \%$ PFA than PCDC especially in the shallower depth of profile $(<25 \mathrm{~mm})$. The slight difference and hence the observation could be attributed to PFA chemical properties. From Table 1, PFA had higher alumina content 
than test ash (in PCDC). This showed that it had a higher proportion of the phase that binds the chlorides. When more chlorides are bound, the diffusivity of chlorides is lowered $[29,30,43-46]$. The binding effect of the PFA may not have been sufficiently predominant to override the other beneficial effects of pozzolana in improving the resistance of the blended cements. It would then seem that the reduction in porosity due to additional cementitious material from pozzolanic reaction and the packaging of the pozzolana grain between aggregates and cement grains played a significant role in improving the resistance of the blended cements [24, 47]. A pozzolanic reaction reduces the pore sizes in blended cement matrix and hence the chloride diffusivity dropped.

At the least $\mathrm{w} / \mathrm{c}$ ratio (0.73), the difference between cement types was not significant whether in bulk or on the shallower depth from exposed surface. This was clearly indicated in Figure 6. Although the mortar cubes were marred with poor workability, there was reduced porosity and higher ability to withstand the chloride ingress into the mortar. These aspects reduced the ingress of chlorides considerably. The beneficial effect of incorporating pozzolanas was not pronounced at this $\mathrm{w} / \mathrm{c}$ ratio. Perhaps this could have been due to limited space for the pozzolana reaction as well as hydration of residual cements. A decreased w/c ratio is a well-known factor in increasing the resistance of concrete/mortar by lowering permeability and porosity [48-55].

It was generally observed that PCDC and OPC $+25 \%$ PFA offered a greater resistance to chloride ingress compared to OPC. The beneficial factor for blended cements was more pronounced in the bulk of the mortar as opposed to the surface. The opposite was true for OPC. The blended cements were thus observed to exhibit resistance to chloride ingress as expected. PCDC exhibited a significant drop in chloride ingress in its bulk. This showed that PCDC would offer a long-term resistance to chloride ingress. This could be attributed to its continued hydration from pozzolanic reaction.

\section{Conclusion}

It was observed that the blended cements showed lower chloride ingress with PCDC exhibiting the least at all w/c ratios. But as the chloride profile showed, the ingress was significantly lowered at greater depth from exposed surface in the blended cements. It would thus imply that while using the cements in structures requiring reinforcement bars, caution has to be taken on the depth from exposed surface.

\section{Data Availability}

The data used to support the findings of this study are available from the corresponding author upon request.

\section{Conflicts of Interest}

The authors declare that there are no conflicts of interest.

\section{Acknowledgments}

The authors would wish to acknowledge Kenyatta University and the University of Manchester for provision of facilities to carry the research. We would also wish to acknowledge the British Council for provision of funds for the research.

\section{References}

[1] M. J. Wachira, M. G. Kanyago, and T. J. Karanja, "Cementing material from rice husk-broken bricks-spent bleaching earthdried calcium carbide residue," Mediterranean Journal of Chemistry, vol. 2, no. 2, pp. 401-407, 2012.

[2] J. M. Marangu, J. K. Thiong'o, and J. M. Wachira, "Chloride ingress in chemically activated calcined clay-based cement," Journal of Chemistry, vol. 2018, Article ID 1595230, 8 pages, 2018.

[3] D. V. Ribeiro, J. A. Labrincha, and M. R. Morelli, "Chloride diffusivity in red mud-ordinary portland cement concrete determined by migration tests," Materials Research, vol. 14, no. 2, pp. 227-234, 2011.

[4] T. R. Naik and R. Kumar, "Sustainable construction materials and technologies: second international conference on sustainable construction materials and technologies," in Proceedings of the Second International Conference on Sustainable Construction Materials and Technologies, J. Zachar, P. Claisse, T. R. Naik, and E. Ganjian, Eds., Ancona, Italy, June 2010, ISBN 978-1-4507-1490-7.

[5] Y. Wang, S. Nanukuttan, Y. Bai, and P. A. M. Basheer, "Influence of combined carbonation and chloride ingress regimes on rate of ingress and redistribution of chlorides in concretes," Construction and Building Materials, vol. 140, pp. 173-183, 2017.

[6] J. M. Marangu, J. K. Thiong'o, and J. M. Wachira, "Review of carbonation resistance in hydrated cement based materials," Journal of Chemistry, vol. 2019, Article ID 8489671, 6 pages, 2019.

[7] N. Amin, S. Alam, and S. Gul, "Effect of thermally activated clay on corrosion and chloride resistivity of cement mortar," Journal of Cleaner Production, vol. 111, pp. 155-160, 2016.

[8] D. M. Bastidas, A. Fernandez-Jimenez, A. Palomo, and J. A. Gonzalez, "A study on the passive state stability of steel embedded in activated fly ash mortars," Corrosion Science, vol. 50, no. 4, pp. 1058-1065, 2008.

[9] S. Islam, S. K. Kaushik, and M. Islam, Physical and Mechanical Behavior of Concrete in Sea Water under High Hydrostatic Pressure, Journal-The Institution of Engineers, Petaling Jaya, Malaysia, 2005.

[10] G.-F. Peng, N.-Q. Feng, and Q.-M. Song, "Influence of chloride-ion adsorption agent on chloride ions in concrete and mortar," Materials, vol. 7, no. 5, pp. 3415-3426, 2014.

[11] M. Aburawi and R. N. Swamy, "Influence of salt weathering on the properties of concrete 2008," Arabian Journal for Science and Engineering, pp. 105-116, 2008.

[12] C. Xiong, L. Jiang, Y. Xu, Z. Song, H. Chu, and Q. Guo, "Influences of exposure condition and sulfate salt type on deterioration of paste with and without fly ash," Construction and Building Materials, vol. 113, pp. 951-963, 2016.

[13] G. Rajasekaran, "Sulphate attack and ettringite formation in the lime and cement stabilized marine clays," Ocean Engineering, vol. 32, no. 8-9, pp. 1133-1159, 2005.

[14] J. Prasad, D. K. Jain, and A. K. Ahuja, "Factors influencing the sulphate resistance of cement concrete and mortar," Asian 
Journal of Civil Engineering (Building and Housing), vol. 7, pp. 259-268, 2006.

[15] M. Safiuddin, A. Kaish, C.-O. Woon, and S. Raman, "Earlyage cracking in concrete: causes, consequences, remedial measures, and recommendations," Applied Sciences, vol. 8, no. 10, p. 1730, 2018.

[16] M. M. Amin, S. B. Jamaludin, F. C. Pa, and K. K. Chuen, "Effects of magnesium sulfate attack on ordinary portland cement (OPC) mortars," Portugaliae Electrochimica Acta, vol. 26, no. 2, pp. 235-242, 2007.

[17] L. S. T. Lee, "Performance deterioration of Portland cement matrix due to magnesium sulfate attack," KSCE Journal of Civil Engineering, vol. 11, no. 3, pp. 157-163, 2007.

[18] M. U. Khan, S. Ahmad, and H. J. Al-Gahtani, "Chlorideinduced corrosion of steel in concrete: an overview on chloride diffusion and prediction of corrosion initiation time," International Journal of Corrosion, vol. 2017, Article ID 5819202, 9 pages, 2017.

[19] E. P. Nielsen and M. R. Geiker, "Chloride diffusion in partially saturated cementitious material," Cement and Concrete Research, vol. 33, no. 1, pp. 133-138, 2003.

[20] X. Zhang and H. Zhao, "Characterization of moisture diffusion in cured concrete slabs at early ages," Advances in Materials Science and Engineering, vol. 2015, Article ID 154394, 10 pages, 2015.

[21] Y.-Y. Kim, K.-M. Lee, J.-W. Bang, and S.-J. Kwon, "Effect of $\mathrm{W} / \mathrm{C}$ ratio on durability and porosity in cement mortar with constant cement amount," Advances in Materials Science and Engineering, vol. 2014, Article ID 273460, 11 pages, 2014.

[22] R. A. Patel, Q. T. Phung, S. C. Seetharam et al., "Diffusivity of saturated ordinary Portland cement-based materials: a critical review of experimental and analytical modelling approaches," Cement and Concrete Research, vol. 90, pp. 52-72, 2016.

[23] J. M. Wachira, J. K. Thiong'o, J. M. Marangu, and L. G. Murithi, "Physicochemical performance of portland-rice husk ash-calcined clay-dried acetylene lime sludge cement in sulphate and chloride media," Advances in Materials Science and Engineering, vol. 2019, Article ID 5618743, 12 pages, 2019.

[24] J. Bai, S. Wild, and B. B. Sabir, "Chloride ingress and strength loss in concrete with different PC-PFA-MK binder compositions exposed to synthetic seawater," Cement and Concrete Research, vol. 33, no. 3, pp. 353-362, 2003.

[25] A. Delnavaz and A. A. Ramezanianpour, "The assessment of carbonation effect on chloride diffusion in concrete based on artificial neural network model," Magazine of Concrete Research, vol. 64, no. 10, pp. 877-884, 2012.

[26] V. Elfmarkova, P. Spiesz, and H. J. H. Brouwers, "Determination of the chloride diffusion coefficient in blended cement mortars," Cement and Concrete Research, vol. 78, pp. 190-199, 2015.

[27] G. K. Glass and N. R. Buenfeld, "The influence of chloride binding on the chloride induced corrosion risk in reinforced concrete," Corrosion Science, vol. 42, no. 2, pp. 329-344, 2000.

[28] J. M. Marangu, J. M. Muthengia, J. W. Thiongo, and Chemistry Department, Kenyatta University-Nairobi, Kenya, "Performance of potential pozzolanic cement in chloride media," IOSR Journal of Applied Chemistry (IOSR-JAC), vol. 7, no. 2, pp. 36-44, 2014.

[29] M. V. A. Florea and H. J. H. Brouwers, "Chloride binding related to hydration products," Cement and Concrete Research, vol. 42, no. 2, pp. 282-290, 2012.

[30] H. Justnes, "A review of chloride binding in cementitious systems," Nordic Concrete Research-Publications, vol. 21, pp. 48-63, 1998.
[31] X. Ke, S. A. Bernal, O. H. Hussein, and J. L. Provis, "Chloride binding and mobility in sodium carbonate-activated slag pastes and mortars," Materials and Structures, vol. 50, no. 6, 2017.

[32] P. O. Awoyera, J. O. Akinmusuru, A. R. Dawson, J. M. Ndambuki, and N. H. Thom, "Microstructural characteristics, porosity and strength development in ceramiclaterized concrete," Cement and Concrete Composites, vol. 86, pp. 224-237, 2018.

[33] P. Chindaprasirt and S. Rukzon, "Strength, porosity and corrosion resistance of ternary blend Portland cement, rice husk ash and fly ash mortar," Construction and Building Materials, vol. 22, no. 8, pp. 1601-1606, 2008.

[34] L. Zingg, M. Briffaut, J. Baroth, and Y. Malecot, "Influence of cement matrix porosity on the triaxial behaviour of concrete," Cement and Concrete Research, vol. 80, pp. 52-59, 2016.

[35] F. Barberon, V. Baroghel-Bouny, H. Zanni et al., "Interactions between chloride and cement-paste materials," Magnetic Resonance Imaging, vol. 23, no. 2, pp. 267-272, 2005.

[36] C. Alonso, C. Andrade, M. Castellote, and P. Castro, "Chloride threshold values to depassivate reinforcing bars embedded in a standardized OPC mortar," Cement and Concrete Research, vol. 30, no. 7, pp. 1047-1055, 2000.

[37] ASTM, Concrete and Aggregates: C1152/C 1152-04: AcidSoluble Chloride in Mortar and Concrete, ASTM International, West Conshohocken, PA, USA, 2005.

[38] B. H. Oh and S. Y. Jang, "Effects of material and environmental parameters on chloride penetration profiles in concrete structures," Cement and Concrete Research, vol. 37, no. 1, pp. 47-53, 2007.

[39] K. M. A. Hossain, "Chloride diffusivity of volcanic ash blended hardened cement paste," Advances in Cement Research, vol. 15, no. 2, pp. 83-90, 2003.

[40] R. Luo, Y. Cai, C. Wang, and X. Huang, "Study of chloride binding and diffusion in GGBS concrete," Cement and Concrete Research, vol. 33, no. 1, pp. 1-7, 2003.

[41] Z. Lafhaj, M. Goueygou, A. Djerbi, and M. Kaczmarek, "Correlation between porosity, permeability and ultrasonic parameters of mortar with variable water/cement ratio and water content," Cement and Concrete Research, vol. 36, no. 4, pp. 625-633, 2006.

[42] O. E. Gjørv and $\varnothing$. Vennesland, "Diffusion of chloride ions from seawater into concrete," Cement and Concrete Research, vol. 9, no. 2, pp. 229-238, 1979.

[43] M. M. Hossain, M. R. Karim, M. K. Hossain, M. N. Islam, and M. F. M. Zain, "Durability of mortar and concrete containing alkali-activated binder with pozzolans: a review," Construction and Building Materials, vol. 93, pp. 95-109, 2015.

[44] M. V. A. Marinescu and H. J. H. Brouwers, "Chloride binding in OPC hydration products," in Proceedings of 17th Ibausil International Conference on Building Materials, Weimar, Germany, H. B. Fischer and K. A. Bode, Eds., Bauhaus-Universitat Weimar, Weimar, Germany, September 2009.

[45] J. H. Potgieter, S. S. Potgieter-Vermaak, D. J. Delport, and S. Verryn, "Chloride-binding effect of blast furnace slag in cement pastes containing added chlorides," South African Journal of Chemistry, vol. 64, pp. 108-114, 2011.

[46] J. Ortega, T. Rosa, I. Sánchez, and M. Climent, "Effects of environment in the microstructure and properties of sustainable mortars with fly ash and slag after a 5-year exposure period," Sustainability, vol. 10, no. 3, p. 663, 2018.

[47] A. Cheng, R. Huang, J.-K. Wu, and C.-H. Chen, "Influence of GGBS on durability and corrosion behavior of reinforced 
concrete," Materials Chemistry and Physics, vol. 93, no. 2-3, pp. 404-411, 2005.

[48] J. Crank, The Mathematics of Diffusion, Clarendon Press, Oxford, UK, 2nd edition, 1975, ISBN 978-0-19-853344-3.

[49] J. M. Wachira, "Effects of chlorides on corrosion of simulated reinforced blended cement mortars," International Journal of Corrosion, vol. 2019, Article ID 2123547, 7 pages, 2019.

[50] Wiley VCH, Corrosion of Steel in Concrete: Prevention, Diagnosis, Repair, L. Bertolini, Ed., Wiley VCH, Weinheim, Germany, 2004, ISBN 978-3-527-30800-2.

[51] D. P. Bentz, "Influence of water-to-cement ratio on hydration kinetics: simple models based on spatial considerations," Cement and Concrete Research, vol. 36, no. 2, pp. 238-244, 2006.

[52] M. Nokken, A. Boddy, R. D. Hooton, and M. D. A. Thomas, "Time dependent diffusion in concrete-three laboratory studies," Cement and Concrete Research, vol. 36, no. 1, pp. 200-207, 2006.

[53] M. D. Thomas and J. Matthews, "Performance of PFA concrete in a marine environment--10-year results," Cement and Concrete Composites, vol. 26, no. 1, pp. 5-20, 2004.

[54] K. O. Kjellsen, R. J. Detwiler, and O. E. Gjørv, "Pore structure of plain cement pastes hydrated at different temperatures," Cement and Concrete Research, vol. 20, no. 6, pp. 927-933, 1990.

[55] H. Yiğiter, H. Yazıcı, and S. Aydın, "Effects of cement type, water/cement ratio and cement content on sea water resistance of concrete," Building and Environment, vol. 42, no. 4, pp. 1770-1776, 2007. 


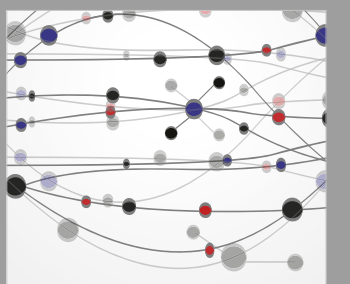

The Scientific World Journal
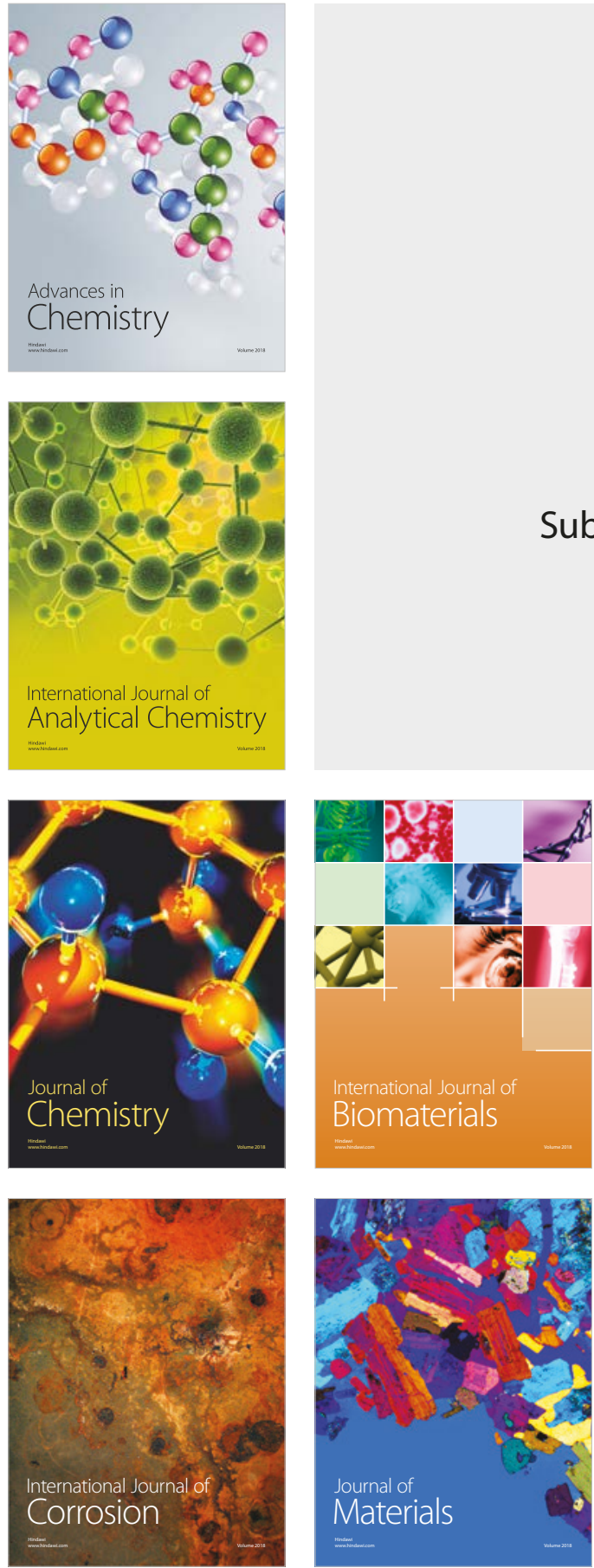

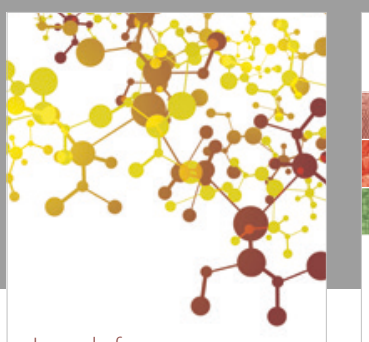

Journal of

Applied Chemistry
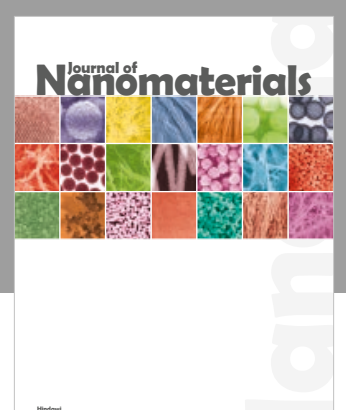

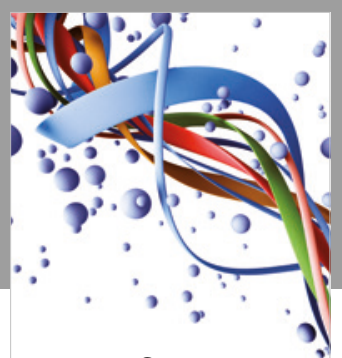

Scientifica

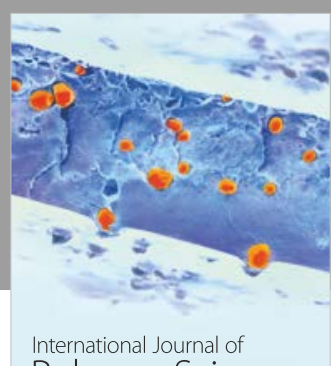

Polymer Science

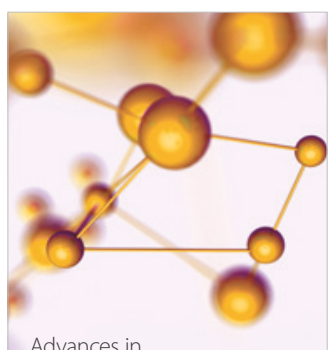

Physical Chemistry
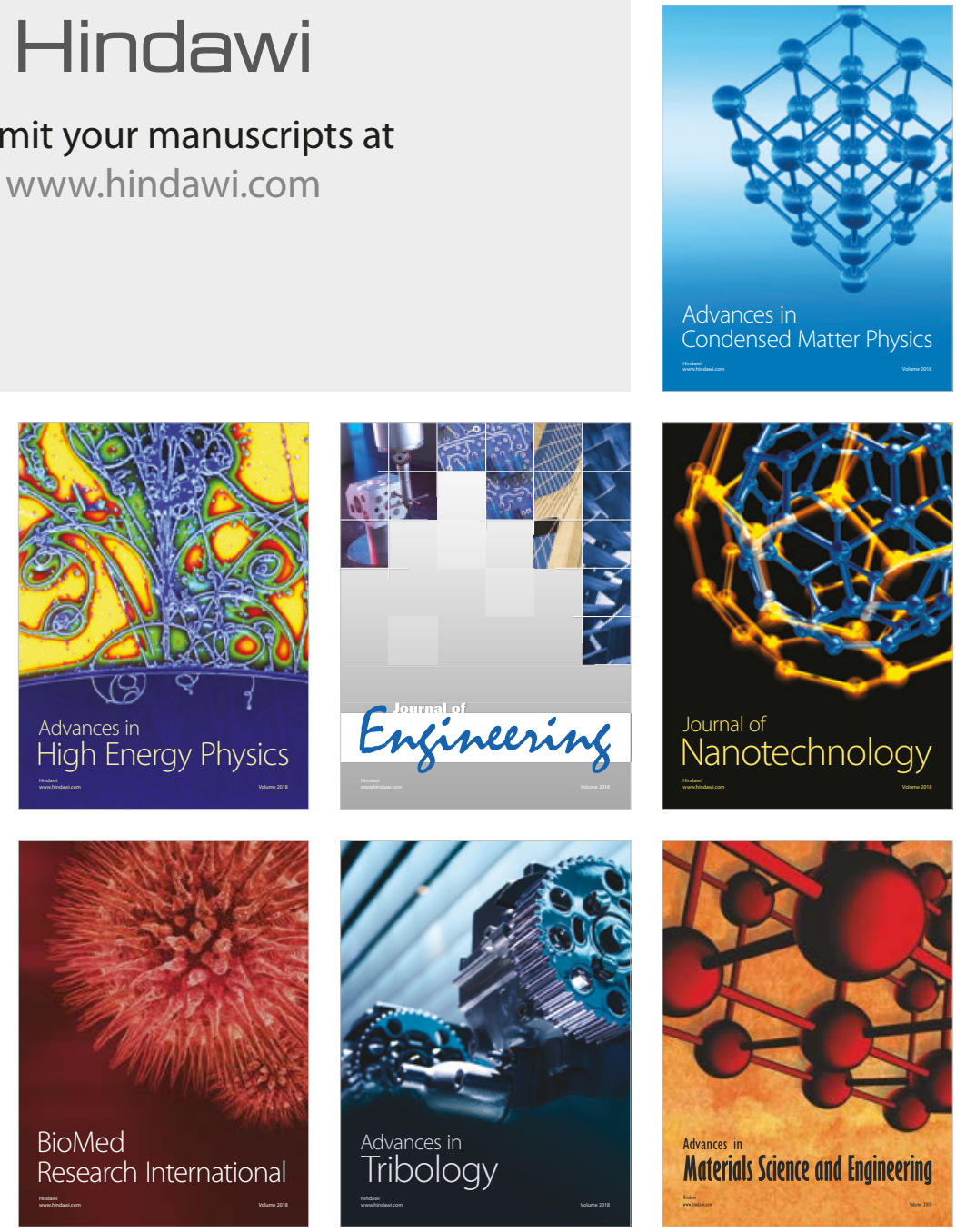